\title{
Nutrient Digestibility and Haematological Indices of West African Dwarf Goats fed Cnidosculus aconitifolius Multinutrient Blocks as supplement
}

\author{
Aye P. A \\ amokapius@yahoo.com \\ Department of Animal Production and Health Sciences \\ Ekiti State University, Ado -Ekiti, Nigeria
}

\begin{abstract}
The study involves twenty-four (12) yearling West African Dwarf Goats. The goats were assigned randomly to three treatments viz: Cnidoscolus-Poultry Manure-Multinutrient Blocks (CPMNB), Cnidoscolus-Urea -Multinutrient Blocks (CUMNB) and control consisting of Panicum maximum and cassava peels. Each treatment consists of eight goats as replicates. They were adequately fed and provided with fresh and clean water. The hematological parameters and nutrient digestibility as influenced by the three treatments were evaluated. The Packed Cell Volume (PCV) value for goats fed the experimental multinutrient blocks ranged from $25.25 \pm 1.25 \%$ in CUMNB to $20.25 \pm 2.25 \%$ in CPMNB and that of the control diet was $19.90 \pm 1.59 \%$. The red blood cell varied from $545 \pm 116.0 \times 10^{6} \mathrm{~mm}^{-1}$ in CUMNB to $335 \pm 64.0 \times 10^{6} \mathrm{~mm}^{-1}$ in CPMNB with control having the value $222.58+25.61 \times 10^{6} \mathrm{~mm}^{-1}$. The White Blood Cell (WBC) was highest in CUMNB $\left(263.5 \pm 1.65 \times 10^{3} \mathrm{~mm}^{-1}\right)$, followed by CPMNB $\left(151.5 \pm 10.8 \times 10^{3} \mathrm{~mm}^{-1}\right)$ while the least value was recorded in the goat fed control diet $\left(137.9 \pm 2.75 \times 10^{3} \mathrm{~mm}^{-1}\right)$. The haemoglobin concentration (HBC) was lowest in goats fed the control diet $\left(5.92 \pm 0.18 \mathrm{~g} 100 \mathrm{~mm}^{-1}\right)$. The Erythrocyte sedimentation rate $\left(\mathrm{mm} \mathrm{hr}^{-1}\right)$ varied from $3.41 \pm 0.1$ in CUMNB to $1.33 \pm 0.34$ in goats fed the control diet. The mean corpuscular volume (MCU) $\mu \mathrm{m}^{-3}$ was highest in goats fed supplemental CUMNB $(8.9 \pm 0.08)$ and lowest in goat fed the control diet $(4.6 \pm 0.6)$. The mean corpuscular Haemoglobin $(\overline{\mathrm{MCH}})(\mathrm{pg})$ was highest in goats fed supplemental CUMNB $(2.66 \pm$ $0.15)$ and lowest in goat fed the control diet $(1.6 \pm 0.55)$. The lymphocyte values were $63.0 \pm$ $2.0 \%, 65.66 \pm 1.34 \%$ and $62.25 \pm 1.25 \%$ for CPMNB, CUMNB and control respectively. Neutrophilis (\%) value for CUMNB was $29.25 \pm 3.25$, CPMNB value was $28.25 \pm 2.67$ and that of the control treatment was $27.25 \pm 1.75$. The Monocytes (\%) value for CUMNB was the highest $(6.4 \pm 0.6)$, followed by CPMNB $(5.0 \pm 0.00)$ and the control treatment has the least value $(4.90 \pm$ $0.42)$. The Eosinophils (\%) values varied from $2.0 \pm 0.25$ in CUMNB to $1.83 \pm 0.17$ in control treatment. The goats fed control diet showed the least values for the haemological variables. The percent digestible nutrient and coefficient of digestibility in the feed showed that goats fed supplemental Cnidoscolus- based multinutrient blocks had better nutrient utilization. Thus better rumen digestion and haematological performance than goats fed diet of Panicum- cassava peels ration.
\end{abstract}

Keywords Haematology, Digestibility, Indices, Nutrient, Supplements.

\section{INTRODUCTION}

Goats have been hampered over the years primarily by the non-availability of good quality and quantity of feed (Onwuka, 1999). This is so for ruminant animals during dry season months when little forage available is low in quantity causing occasional weight losses, low birth weight, lowered resistance diseases and reduced animal performance (Onwuka et al., 1992).

Furthermore, the limited supply of raw materials for the livestock feed industry has resulted in a continuous increase in the cost of production, causing phenomenal rise in the unit cost of production of livestock (Onwuka et al., 1992). The shortage of good quality feed needed to sustain livestock growth especially during dry season months has been a perennial problem which can be reduced or eliminated by finding alternative source of protein and energy concentrate mixture given to animal.

In many under developed countries, malnutrition has been identified as the single most important public health problem (Adeyeye and Afolabi, 2004). The nutritional requirement of the human body reflects the nutritional intake necessary to maintain optimum 
Agric. Biol. J. N. Am., 2013, 4(4): 375-383

body function to meet the body's daily energy needs (F.A.O, 1999). Malnutrition which is defined as inadequate nutrition is been interpreted as under nutrition or over-nutrition. The etiology of malnutrition includes factors such as poor food availability in good quality and quantity and preparation, recurrent infections etc. Consequently, the indices of nutritional disease and malnutrition are on the increase (F.A.O., 1999). The recommended total protein intake for normal growth and development in human is $85.99 \mathrm{~g}$ per person per day, out of which approximately $39 \mathrm{~g}$ should be from animal origin but an average Nigerian consumes about 33g (Adegbola, 2002). This therefore calls for an increase in livestock production in order to improve the nutritional status of Nigerians through provision of high quality animal products such as meat, milk and eggs.

This therefore calls for a reasonable level of feed supplementation in small ruminant e.g. goats with particular emphasis on the energy, protein and minerals. Multinutrient blocks which is an alternative feed resource has been advocated as a panacea to protein and energy deficiencies in ruminant especially during dry season (Aye, 2005; Aye, 2012), Multinutrient block provides primarily the needs of the rumen micro organism, it is a rich source of fermentable nitrogen, minerals, vitamins, amino acids and peptide.

Mulnutrient blocks can be made from farm wastes such as Cnidoscolus aconitifolious leave residues, molasses, urea, cement and salt (Hassoun and $\mathrm{Ba}$, 1991). Molasses and urea, which are components of multinutrient blocks, are known to respectively contain available energy and nitrogen and are used in feeding ruminant (Preston and Leng, 1990). Pickstock (1985)reported that in times of drought, when energy and protein reserves of animals fall to dangerously low levels, molasses - urea mixtures fed in amount of up to $2 \mathrm{~kg}$ a day, helped to satisfy both energy and protein needs for maintenance of ruminant. These will upgrade the energy and ammonia levels in the ruminant's rumen (Mancini et al., 1997).

The significance of determining hematological and biochemical indices of domestic animals has been well documented (Tambuwal et al., 2002; Orheruata and Aikhuomobhogbe, 2006). There is a great variation in the haematological and biochemical parameters as observed between breeds of goats (Meyer and Harvey, 1998). Normal blood values are defined as those of clinically healthy animals which are kept under normal housing conditions and fed balance ration. Meyer and Harvey (1998) noted that the ingestion of numerous dietary components have measurable effect on blood constituent.

This study is designed to evaluate nutrient utilization and hematological parameters of West African Dwarf goats fed Cnidoscoous aconitifolious - based multinutrient blocks.

\section{MATERIALS AND METHODS}

Study Area: The experiment was carried out at the Small Ruminant unit of Teaching and Research Farms of the Ekiti State University, Ado Ekiti, Ekiti State.

The pens used were cleaned and disinfected with germicide, cleaning of feeder and water troughs were carried out before the arrival of the animals.

Procurement of the West African Dwarf (WAD) Goats: Twenty-four yearling WAD goats were purchased from the Otun market in Ekiti State of Nigeria. They were quarantined for 4 weeks during which routine treatment develop at NAPRI (1984) and modified by Aye (1998) was applied.

Experimental layout and Animal management: The pen was partitioned into twenty-four equidimensional unit with plants. The goats were weighed into their experimental units, efforts were made to ensure that all the treatments were balanced in body weight. The design of the experiment was a completely randomized designed. The animals were randomly assigned to three treatments and each treatment has four goats as replicates. The goats were fed basal diet consist of cassava peels and Panicum maximum and experimental multinutrient blocks.

The treatments were as follows;

Treatment 1- Panicum maximum + Cassava peels supplemented with Cnidoscolus-Poultry manure based multi-nutrient blocks (CPMNB)

Treatment 2- Panicum maximum + Cassava peels supplemented with Cnidoscolus-Urea-based multinutrient blocks (CUMNB).

Treatment 3- Panicum maximum +Cassava peels only

Fresh cassava peels were obtained from gariprocessing factory in Iworoko-Ekiti, the fresh cassava peels were sun-dried for about 5-7 days depending on weather condition. 
Guinea grass was harvested $1 \mathrm{~m}$ from the base of the plant with sickle. The stems and leaves were still succulent and had not lignified. It was chopped into small pieces with a cutlass so as to prevent wastage by the animals; the grass was wilted for about 2 days to prevent scouring in animals.

Table 3: Ingredient Composition

(\%) of experimental multinutrient blocks

\begin{tabular}{|l|c|c|}
\hline Ingredients & CPMNBS & CUMNBS \\
\hline Molasses & 40 & 40 \\
\hline Urea & - & 10 \\
\hline Poultry manure & 10 & - \\
\hline Salt & 5 & 5 \\
\hline Cement & 15 & 15 \\
\hline $\begin{array}{l}\text { Cnidoscolus } \\
\text { residues }\end{array}$ & 30 & 30 \\
\hline Total & $\mathbf{1 0 0}$ & $\mathbf{1 0 0}$ \\
\hline
\end{tabular}

Leaves of Cnidoscolus aconitifolius were harvested in fresh condition from various locations in Ekiti State (Iworoko-Ekiti and Emure-Ekiti) and Ondo State (Akure).

The harvested leaves were pulped with leaf pulping machine, followed by processing with a screw-press as described by Fellow (1987) and modified by Aye (2007). The fibrous residues were thereafter separated from the leaf juice by filtering through Muslin cloth followed by pressing with screw press as described for gari making (Aletor, 1993). The fibrous residues were then pulverized and spread in the sun to dry. The dried fibrous residues were ground with laboratory hammer mill and kept in airtight container prior to its use.

Preparation of Multinutrient Blocks:Two multinutrient blocks were produced as described by Aye (2012).The components were thoroughly mixed manually, cement was first mixed with water at the rate of $(50 / 100)(w / w)$. Cnidoscolus residues, molasses, urea or poultry manure, salt was added in that order and the cement was added last. The mixture was poured into a cellophane-lined plastic mould. The cellophane paper was used to facilitate the removal of multinutrient blocks when formed. The molded multinutrient blocks were air dried under shade for about 7 days.
Feeding Trial: The feeding trial lasted for 12 weeks, when animals were fed on basal diets containing cassava peels and Panicum maximum supplemented with Cnidoscolus-based multi-nutrient blocks. The goats were adapted for 10 days to the experimental diets before actual data collection commenced. Measurements of haematological indices were done at the start and fortnightly.

Blood Collection: Blood was collected from the jugular vein of the goats at the start and fortnightly for analysis of blood indices. The blood was collected into a vial containing Ethylenediaminetetral acetic acid (EDTA), which prevents coagulation by complexing $\mathrm{Ca}^{2+}$. The vials were immediately capped and content rocked gently for about a minute by repeated inversion.

Packed Cell Volume (Haematocrit): Packed cell volume (PCV) was determined by spinning about $7 \mu 1$ of each blood sample in heparinised capillary tubes in a haematocrit centrifuge for about 5 minutes. The PCV was then read on haemotocrit readers as described by Benson et al. (1989) and Jain (1993).

Erythrocyte (Red blood count): Red blood count was determined using haemocytometer method as described by Lamb (1981). The blood sample collected in each replicate was diluted at a ratio of 1:200 and RBC were obtained using the prerelationship Red Blood Cell/ $\mu \mathrm{L}=$ Number of cell counted X 5X 200.

Haemoglobin estimation: The haemoglobin content in the blood of each goat was estimated using Cyanomethaemoglobin method. $0.02 \mathrm{ml}$ of blood from each goat was expelled into $4 \mathrm{ml}$ Drabkins solution. The mixture was allowed to stand for 5 minutes for full colour development. Also, standard hemoglobin was prepared by diluting blood of known haemoglobin concentration as in the test sample. The test samples and standard were read on the colourimeter at 624 manometers using green filter.

Samples haemoglobin concentration was obtained using this relationship sample haemoglobin

$=\underline{\text { Reading of test }} \times$ Standard Haemoglobin Conc. $(\mathrm{g} / 100 \mathrm{ml})$

Reading of Standard

Haemoglobin indices also measured were erythrocyte sedimentation rate (ESR) Lymphocytes, Neutrophils, Monocytes, Eosinphils and Basophils.

Nutrient Utilization: This was carried out by transferring goats into wooden metabolic cage fitted with facilities to separately collect urine and faeces. 
Each goat was allocated individual metabolic cage for 14 days. The quantity of feed offered, feed refusal, faeces and urine were determined for 7 days after 7 days of adjustment to the cages.

Collection of Urine $20 \mathrm{~cm}^{3}$ of $10 \%$ concentrated $\mathrm{H}_{2} \mathrm{SO}_{4}$ was added to each bowl, which was used to collect the urine of animals to prevent Nitrogen loss, bacteria growth infestation. The volume of urine was measured and recorded daily each morning. $10 \%$ of the urine collected from each animal was poured into a well-labeled urine collection bottle and stored in a refrigerator prior to laboratory analysis.

Collection of Faeces The faeces were collected from individual animal. 10\% of the feaces collected daily over the 7-day period were bulked and weighed and used for moisture determination. The remaining feaces were oven dried at $70^{\circ} \mathrm{C}$ for 36 hours, milled and stored in air tight bottles.

Analytical Procedures: Samples of feeds and faeces were ground in a hammer mill to pass a $1 \mathrm{~mm}$ mesh sieve for their proximate compositions according to the procedure described by AOAC (2005). Nitrogen contebnts of feed, faeces and urine were determined by the micro-kjeldahl technique using the Markham's distillation apparatus. Results obtained were used for the calculation of digestibility of nutrients and Nitrogen balance for the experimental animals. Gross energy of feed was measured by bomb calorimetry using benzoic acid as a standard $(26437 \mathrm{j} / \mathrm{g})$.

Statistical Analysis: Data obtained were subjected to one-way analysis of variance using ANOVA procedure of Minitab Statistical Package (Minitab USA) version 10.2. Means were separated using Duncan's Multiple Range Test (Duncan, 1955).

\section{RESULTS AND DISCUSSION}

Diet Composition: Table 1 shows the proximate analysis of the Cnidoscolus residue, cassava peels, guinea grass and multinutrient blocks.

The Cnidoscolus residue contained $94.54 \pm 0.02 \mathrm{~g}$

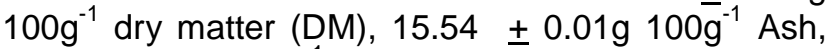

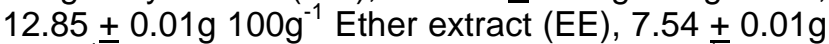
$100 \mathrm{~g}^{-1}$ Crude Fibre (CF), $25.77 \pm 1.14{\mathrm{~g} 100 \mathrm{~g}^{-\top} \text { Crude }}^{-1}$

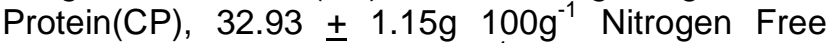
Extract (NFE) and $1 \overline{4} .71 \mathrm{MJ} \mathrm{kg}^{-1}$ Gross Energy (GE)

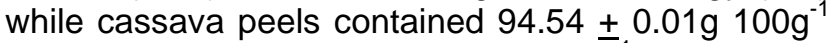
dry matter (DM), $6.89 \pm 0.01 \mathrm{~g} 100 \mathrm{~g}^{-1}$ Ash, $6.90_{ \pm}$

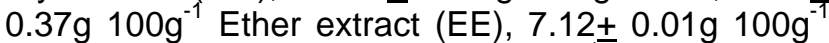

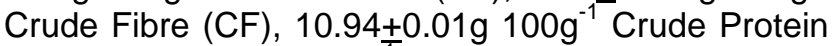
(CP), 62.67 $\pm 0.41 \mathrm{~g}^{100 \mathrm{~g}^{-1}}$ Nitrogen Free Extract (NFE) and $15.59 \mathrm{MJ} \mathrm{kg}^{-1}$ Gross Energy (GE).

Table 1. Proximate Analysis of Cnidoscolus Residues, Cassava peels, Gunea grass and Experimental Multinutrient Blocks

\begin{tabular}{|l|l|l|l|l|l|}
\hline Composition & Cnidoscolus residues & Cassava peel & Guinea grass & CPMNB & CUMNB \\
\hline Dry matter & $94.54 \pm 0.02$ & $94.54 \pm 0.01$ & $91.47 \pm 0.01$ & 69.93 & 67.15 \\
\hline Ash & $15.54 \pm 0.001$ & $6.89 \pm 0.01$ & $7.21 \pm 0.01$ & 23.24 & 22.81 \\
\hline Ether Extract & $12.85 \pm 0.01$ & $6.90 \pm 0.37$ & $5.32 \pm 0.01$ & 0.72 & 0.1 \\
\hline Crude fibre & $7.54 \pm 0.01$ & $7.12 \pm 0.01$ & $35.21 \pm 0.02$ & 5.51 & 3.51 \\
\hline Crude protein & $25.77 \pm 1.14$ & $10.94 \pm 0.01$ & $16.14 \pm 0.45$ & 31.97 & 34.83 \\
\hline Nitrogen Free Extract & $32.93 \pm 1.15$ & $62.67 \pm 0.41$ & $36.09 \pm 0.20$ & 38.56 & 35.73 \\
\hline Gross Energy (MJkg & 14.71 & 15.99 & 12.00 & 16.33 & 15.74 \\
\hline
\end{tabular}

CPMNB - Cnidoscolus + Poultry Manure Multinutrient Block

CUMNB - Cnidoscolus + Urea Multinutrient Block

Control - Panicum maximum + Cassava Peel

The Panicum maximum contained $91.47 \pm 0.01 \mathrm{~g}$

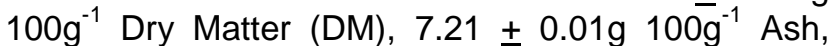

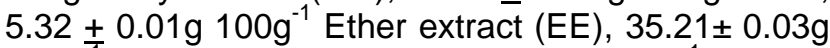
$100 \mathrm{~g}^{-1}$ Crude fibre, $16.14 \pm 0.45 \mathrm{~g} 100 \mathrm{~g}^{-1}$ Crude

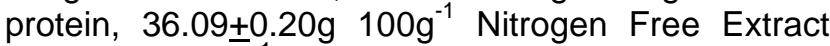
and $12.00 \mathrm{MJ} \mathrm{kg}^{-1}$ Gross Energy (GE).
The proximate composition of the experimental feed

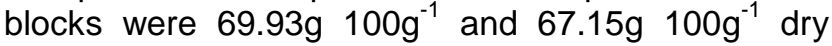
matter (DM) in Cnidoscolus poultry manure Multinutrient block (CPMNB) and Cnidoscolus urea multinutrient block (CUMNB) respectively , $23.24 \mathrm{~g}$

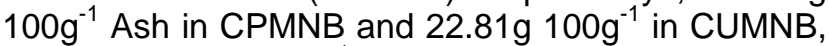

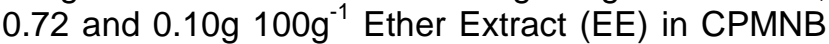


and CUMNB respectively, Crude fibre were 5.51 and

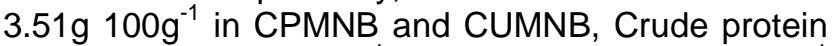

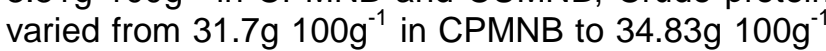
in CUMNB, Nitrogen free extract ranged from $35.73 \mathrm{~g}$ $100 \mathrm{~g}^{-1}$ in CUMNB to $38.56 \mathrm{~g}^{100 \mathrm{~g}^{-1}}$ in CPMNB and Gross Energy were 15.74 and $16.33 \mathrm{MJ} \mathrm{kg}^{-1}$ in CUMNB and CPMNB respectively.

Table 2 shows the energy values as contributed by protein, fat and carbohydrate in the Cnidoscolusbased multinutrient blocks. The proportion of total energy due to protein (PEP) ranged from $70.72 \%$ in CPMNB to $90.33 \%$ in CUMNB. Proportion of total energy due to fat varied from $0.51 \%$ in CUMNB to $3.47 \%$ in CPMNB. Proportion of total energy due to carbohydrate (PEC) varied from $9.10 \%$ in CUMNB to $25.81 \%$ in CPMNB. Utilizable energy due to protein is higher in CPMNB (461.11) than CUMNB (437.05)
Table 2. Energy Values as Contributed by Protein, Fat, Carbohydrate in the Cnidoscolus-Based Multinutrient Blocks

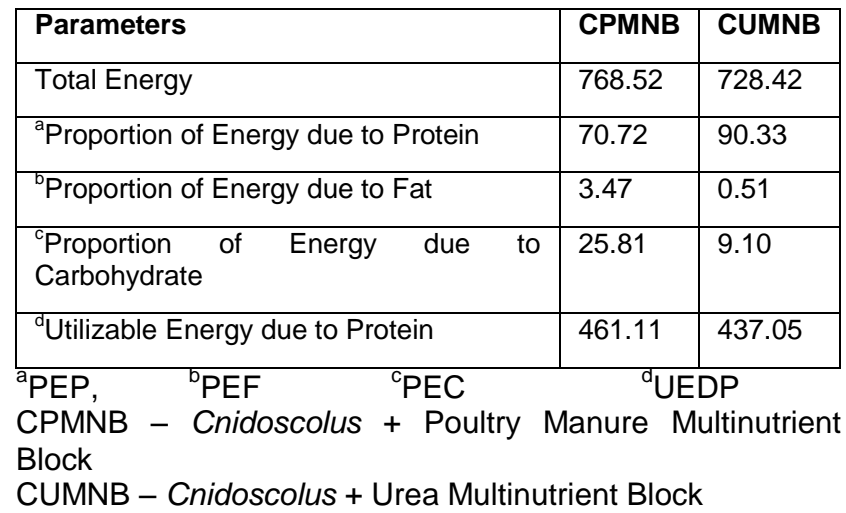

Table 3 presents the haematological parameters as influenced by the three treatments.

Table 3. Haematological Variables of West African Dwarf Goat Fed Cnidoscolus aconitifolius -Based Multinutrient Block

\begin{tabular}{|l|l|l|l|}
\hline Parameters & CPMNB & CUMNB & Control \\
\hline Packed Cell Volume (\%) & $20.25 \pm 2.25$ & $25.25 \pm 1.25$ & $19.90 \pm 1.59$ \\
\hline Red blood cell $\left(\times 10^{6} \mathrm{~mm}^{-1}\right)$ & $9.35 \pm 0.40$ & $8.45 \pm 1.16$ & $6.22 \pm 0.67$ \\
\hline White Blood Cell $\left(\times 10^{3} \mathrm{~mm}^{-1}\right)$ & $11.5 \pm 1.08$ & $10.5 \pm 1.05$ & $13.9 \pm 1.05$ \\
\hline Haemoglobin Conc. $\left(\mathrm{g} 100 \mathrm{~mm}^{-1}\right)$ & $7.1 \pm 0.39$ & $8.8 \pm 0.89$ & $5.92 \pm 0.18$ \\
\hline Erythrocyte Sedimentation Rate (mmhr $\left.{ }^{-1}\right)$ & $3.41 \pm 0.1$ & $3.33 \pm 0.39$ & $1.33 \pm 0.34$ \\
\hline Mean Corpuscular Haemoglobin Con. (\%) & $31.65 \pm 1.64$ & $34.85 \pm 4.29$ & $20.75 \pm 3.37$ \\
\hline Mean Corpuscular Haemoglobin (pg) & $1.91 \pm 0.33$ & $2.66 \pm 0.15$ & $1.6 \pm 0.55$ \\
\hline Mean Corpuscular Volume ( $\left.\mu \mathrm{m}^{3}{ }^{3}\right)$ & $26.0 \pm 1.14$ & $28.9 \pm 0.08$ & $24.6 \pm 0.6$ \\
\hline Lymphocyte (\%) & $63.0 \pm 2.0$ & $65.66 \pm 1.34$ & $60.25 \pm 1.25$ \\
\hline Neutrophils (\%) & $28.66 \pm 2.67$ & $29.25 \pm 3.25$ & $25.25 \pm 1.75$ \\
\hline Monocytes (\%) & $6.01 \pm 0.00$ & $6.41 \pm 0.6$ & $4.90 \pm 0.42$ \\
\hline Eosinophils (\%) & $2.0 \pm 0.00$ & $2.0 \pm 0.25$ & $1.83 \pm 0.17$ \\
\hline Basophils (\%) & $1.08 \pm 0.41$ & $1.08 \pm 0.09$ & $1.0 \pm 0.00$ \\
\hline
\end{tabular}

CPMNB - Cnidoscolus + Poultry Manure Multinutrient Block

CUMNB - Cnidoscolus + Urea Multinutrient Block

Control - Panicum maximum + Cassava Peel

The packed cell volume (PCV) value for goats fed the experimental multinutrient blocks ranged from $20.25 \pm 2.25 \%$ in CPMNB to $25.25 \pm 1.25 \%$ in CUMNB compared to PCV value of $19.90 \pm 1.59 \%$ in the control diet. The red blood cell varied from $8.45 \pm 1.16 \times 10^{6} \mathrm{~mm}^{-1}$ in CUMNB to $9.35 \pm 0.40 \times 10^{6} \mathrm{~mm}$
${ }^{1}$ in CPMNB with control treatment having the value $6.22 \pm 0.67 \times 10^{6} \mathrm{~mm}^{-1}$. The white blood cell (WBC) was highest in the control treatment $\left(13.9 \pm 1.05 \times 10^{3} \mathrm{~mm}^{-}\right.$ $\left.{ }^{1}\right)$, followed by CPMNB $\left(11.5 \pm 1.08 \times 10^{3} \mathrm{~mm}^{-1}\right)$ while the least value was recorded in the goats fed CUMNB $\left(10.5 \pm 1.05 \times 10^{3} \mathrm{~mm}^{-1}\right)$. The haemoglobin concentration ( $\mathrm{HBC})$ was lowest in goats fed the 
control diet $\left(5.92 \pm 0.18 \mathrm{~g} 100 \mathrm{~mm}^{-1}\right)$, and the highest value recorded was in goats fed CUMNB $(8.8 \pm 0.89 \mathrm{~g}$ $\left.100 \mathrm{~mm}^{-1}\right)$. The Erythrocyte sedimentation rate $(\mathrm{mm} / \mathrm{hr})$ varied between $1.33 \pm 0.34$ in goats fed the control diet and $3.41 \pm 0.1$ in goats fed supplemental CPMNB. The mean corpuscular volume (MCV) $\mu \mathrm{m}-3$ was highest in goats fed supplement of CUMNB $(28.9 \pm 0.08)$ and lowest in goat fed the control diet $(24.6 \pm 0.6)$. The mean corpuscular Haemoglobin $(\mathrm{MCH})(\mathrm{pg})$ was highest in goats fed supplemental CUMNB $(2.66 \pm 0.15)$ and lowest in goat fed the control diet $(1.6 \pm 0.55)$. The lymphocyte values were $63.0 \pm 2.0 \%, 65.66 \pm 1.34 \%$ and $60.25 \pm 1.25 \%$ for CPMNB, CUMNB and control treatment respectively. Neutrophils (\%) value for CUMNB was $29.25 \pm 3.25$, CPMNB was $28.25 \pm 2.67$ and that of the control treatment was $25.25 \pm 1.75$. The Monocytes (\%) value for CUMNB was the highest $(6.41 \pm 0.6)$, followed by CPMNB $(6.01 \pm 0.00)$ and the control treatment has the least value $(4.90 \pm 0.42)$.

The Eosinophils and Basophils (\%) values of the multinutrient blocks and control treatments were not significantly different $(\mathrm{P}<0.05)$.

The goats fed control diet showed the least values for the haematological variables. Thus the blood profiles of the goats were influenced by the dietary treatments.

Table 4 presents the digestibility coefficient of nutrients of West African Dwarf (WAD) goats fed Panicum-Cassava peels ration supplemented with or without Cnidoscolus aconitifolius - based multinutrient blocks.

Table 4. Digestibility Coefficient Values of West African Dwarf Goat Fed Cnidoscolus aconitifolius -Based Multinutrient Block

\begin{tabular}{|l|l|l|l|}
\hline Nutrients & CPMNB & CUMNB & Control \\
\hline Dry Matter & 85.36 & 85.09 & 68.66 \\
\hline Ash & 79.10 & 71.20 & 59.21 \\
\hline Ether Extract & 60.20 & 53.25 & 52.78 \\
\hline Crude Fibre & 92.21 & 91.67 & 76.46 \\
\hline Crude Protein & 82.41 & 75.17 & 70.58 \\
\hline $\begin{array}{l}\text { Nitrogen Free } \\
\text { Extract }\end{array}$ & 92.87 & 91.88 & 71.99 \\
\hline
\end{tabular}

CPMNB - Cnidoscolus + Poultry Manure Multinutrient Block

CUMNB - Cnidoscolus + Urea Multinutrient Block

Control - Panicum maximum + Cassava Peel

Variation observed among the treatments reveal that all the nutrients measured were significantly $(P<0.05)$ influenced by the treatments. The coefficient of digestibility of dry matter $(68.66 \%)$, crude protein $(70.58 \%)$, crude fibre $(76.46 \%)$, ether extract $(52.78 \%)$ and nitrogen free extract $(71.99 \%)$ of the goats on the control ration were consistently lower $(\mathrm{P}<0.05)$ than those fed the Cnidoscolus based multinutrient blocks supplemented rations (85.09-85.36\% DM), (75.17-82.41\% CP), (91.67$92.21 \%$ CF), (53.25-60.20\% EE) and (91.88-92.87\% NFE). Within the multinutrient blocks supplemented rations goats on CPMNB had higher coefficient of digestibility of all nutrients determined.

Table 5 presents the percent of digestible nutrients in the feed. The dry matter (DM) values was highest in CUMNB (42.24\%), followed by CPMNB (42.05\%) and the control treatment had the least value $(33.99 \%)$. The Ether extract values were $1.25 \%, 1.41 \%$ and $1.07 \%$ for CPMNB, CUMNB and control treatment respectively. The \% digestible crude fibre (CF) values was highest in CUMNB (6.72\%), followed by CPMNB $(6.32 \%)$ and the least value was obtained in control treatment $(6.18 \%)$. The crude protein (CP) values were $4.26 \%, 7.73 \%$ and $4.21 \%$ for CPMNB, CUMNB and control treatment respectively. The Nitrogen Free Extract (NFE) values varied from 21.9 in control treatment to 27.34 in CPMNB. The \% digestible crude protein, crude fibre, ether extract and nitrogen free extracts of the goats on the control ration were significantly $(P<0.05)$ lower than those fed on multinutrient blocks supplemented rations. Within the feed blocks supplemented rations, goats on CUMNB had higher \% digestible crude protein, dry matter, ether extract and crude fibre than those on supplemental CPMNB. Goats on CPMNB had higher $\%$ digestible nitrogen free extract.

Table 5. Percent Digestible Nutrient in the Feed

\begin{tabular}{|l|l|l|l|}
\hline Nutrients & CPMNB & CUMNB & Control \\
\hline Dry Matter & 42.05 & 42.24 & 33.99 \\
\hline Ash & 5.9 & 5.01 & 2.07 \\
\hline Ether Extract & 1.25 & 1.41 & 1.07 \\
\hline Crude Fibre & 6.32 & 6.72 & 6.18 \\
\hline Crude Protein & 4.26 & 7.73 & 4.21 \\
\hline $\begin{array}{l}\text { Nitrogen Free } \\
\text { Extract }\end{array}$ & 27.34 & 22.10 & 21.9 \\
\hline
\end{tabular}

CPMNB - Cnidoscolus + Poultry Manure Multinutrient Block CUMNB - Cnidoscolus + Urea Multinutrient Block

Control - Panicum maximum + Cassava Peel 


\section{DISCUSSION}

The proximate composition of Panicum maximum obtained in this study was at variance with the result obtained by Ogunsola (2005). The value recorded for crude protein was $6.72 \mathrm{~g} 100 \mathrm{~g}-1$, which is lower than

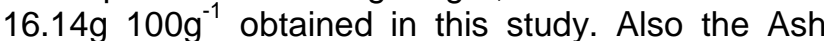
and Ether extract values obtained in this study were at variance with the result reported by Ogunsola (2005). However, crude fibre value obtained in this study agreed with what has been reported in literature (Ogunsola ,2005; Aye, 2007).

The cassava peels used this study has dry matter

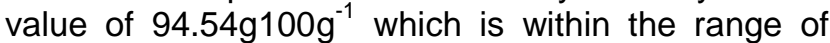

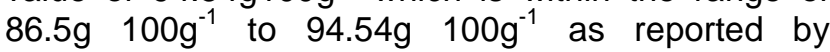
Adegbola (1980), Aye and Adegun(2010). The Ash

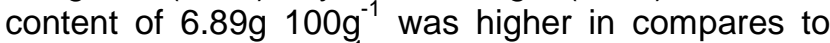
the value $5.95 \mathrm{~g}^{100 \mathrm{~g}^{-1}}$ obtained by Adegun et al. (2011). The crude protein value of $10.94 \mathrm{~g}^{100 \mathrm{~g}^{-1}}$ was higher than the value of $5.30 \mathrm{~g}^{100 \mathrm{~g}^{-1}}$ reported in literature (Adegun et al.,2011). The value of crude fibre $10.94 \mathrm{~g}^{100 \mathrm{~g}^{-1}}$ fell within the range of 10 $31 \mathrm{~g}^{100 \mathrm{~g}^{-1}}$ reported in literature ( Devendra, 1977; Adegbola, 2002; Adegun et al., 2011).

The differences in these values obtained from this study with those of other workers might be due to the stage of harvesting of the plant and processing methods adopted.

Cnidoscolus-urea multinutrient blocks had higher crude protein value of $34.83 \mathrm{~g}^{100 \mathrm{~g}^{-1}}$ compared to Cnidoscolus-poultry manure multinutrient block and this may be due to the presence of urea with a very high content of nitrogen.

Report from literature showed blood indices are important for the assessment of the nutritive component of a given ration (Aletor and Egberongbe, 1992; Agbede and Aletor, 2003).

The white blood cell (WBC) was significantly higher $(\mathrm{P}<0.05)$ in the control group than in animals fed the MNBs, but all the other haematological indices were significantly $(P<0.05)$ higher with supplemental diets. WBC obtained in animals fed supplemental MNBs were within normal range of $4.0-12.0 \times 10^{3} \mathrm{~mm}^{-1}$ for goats (Byanet et al., 2008). The neutrophil counts, PCV, RBC and other calculated haematological values were within normal range for goats (Jain, 1993; Ikhimoya and Imasuen, 2007). It has been reported that haematological indices give insight into the production potential and help to monitor and evaluate incidence of diseases in animals (Karesh and Cook, 1985; Orheruata and Aikhuomobhogbe, 2006).

This tends to show that the feeding of the multinutrient blocks did not have adverse effect on the health status of animals. Therefore, the inclusion of urea or poultry manure at $10 \%$ in these block packages further confirmed the earlier report of Habib et al. (1991) that urea at this level will not pose any health hazard on the animals.

The significant higher nutrient digestibility in goats fed Cnidoscolus- based multinutrient blocks as observed in this study over the control treatment group was due to the non- protein nitrogen used in the Multinutrient Blocks which appears to favour proper functioning of rumen microorganisms. This result shows that the West African Dwarf Goats fed supplemental

\section{CONCLUSION}

This study demonstrates that goats fed CnidoscolusBased Multinutrient Block had better performance than those fed control diet of Panicum-cassava peels only. This shows that the multinutrient blocks have enhanced performance of the goat by efficiently improving rumen fermentation digestion, this providing a better balance of nutrient to the animals for absorption. Further, this study clearly demonstrates that multinutrient blocks feeding is a useful strategy in overcoming dry season weight losses or rather poor performance in goats fed cut and carry fodder. The haematological studies showed that the multinutrient blocks were not detrimental to animal health and well-being and therefore could be used to supplement Panicum-cassava peels in goats feeding.

\section{REFERENCES}

Adegbola T. A. (2002) Nutrient intake, digestibility and rumen metabolites in bulls fed rice straw with or without supplements. Nig. J. Anim. Prod. 29(1) 40-46.

Adegun M. K; Aye P.A and Dairo F.A.S(2011) Evaluation of Moringa oleifera, Gliricidia sepium and Leucaena leucocephala-based multinutrient blocks as feed supplements for sheep in South Western Nigeria. Agriculture and Biology Journal of North America 2(11):1395-1401.

Adeyeye E.I and Afolabi E.O (2004) Amino acid composition of three different types of land snails consumed in Nigeria. Food Chem. 85:535-539. 
Agbede J. O. and Aletor V. A. (2003) Evaluation of fish meal replaced with leaf protein concentrate from Gliricidia in diets for broiler-chicks. Effect on performance, muscle growth and haematology and serum metabolites. International Journal of Poultry Science 2(4):242-250.

Aletor V. A. (1993) Cyanide in gari 2. An assessment of some aspects of the nutrition, biochemistry and haematology of the rat fed gari containing varying residual cyanide levels. Inter. J. Food Sci. 44: 289-295.

Aletor V. A. and Egberongbe O. (1992) Feeding differently processed Soyabean. Part 2: An assesment of haematological responses in the characteristics, haematology and sepium chemistry of chickens. Die Nahrung 36:364-369.

AOAC (2005) Association of Official Analytical Chemist. Official Methods of Analysis. 18th edn. (Association of Official Analytical Chemists Gaithersburg USA) AOAC Press Pp 1250-1255.

Aye P. A. (1998) The effect of two management systems on some physiological parameters and growth rate of the West African Dwarf goats. M. Tech. Thesis. Federal University of Technology Akure, Nigeia.

Aye P. A. (2005) Development of Multinutrient blocks for the small ruminants in Nigeria. Proceedings 10th Annual ASAN Conference Sept. 12-15 2005. pp 195-196.

Aye P. A (2007) Production of multinutrient blocks for ruminants and alcohol from the waste products of Leucaena leucocephala and Gliricidia sepium leaves using local technologies. Ph.D Thesis. Federal University of Technology, Akure.

Aye P. A and Adegun M.K (2010) Digestibility and growth in West African dwarf sheep fed gliricidiabased multinutrient block supplements. Agriculture and Biology Journal of North America 1(6):1133-1139.

Aye P. A (2012) Production of Gliricidia and Leucaena -based multinutrient blocks as supplementary ruminant feed resource in South Western Nigeria. Agriculture and Biology Journal of North America 3(5)213-220

Benson H. J.; Gunstream S. E.; Talaro A. and Tolaro K. P. (1989) Anatomy and Physiology. Laboratory textbook. WMC Brown Publisher Dubuque IOWA.
Byanet O; Adamu S; Salami S.O and Onagiah H. I(2008) Haematological and plasma biochemical parameters of the young grasscutter (Thyronomys swinderianus) reared in Northern Nigeria. Journal of cell and Animal Biology 2(10):177-181.

Devendra C. (1977) Cassava as feed source for ruminants. In cassava as animal feed. In: B. Nestel and M. Grasham. (eds.) IDRC - 095e Guelph Pp 107-127.

Duncan D. G (1955) Multiple Range and multiple Ftest. Biometrics 11:1-42

FAO (1999) Utilization of tropical foods. Food and Nutrition Paper 47/1 Rome, Italy.

Fellows P. (1987) Village-Scale leaf fractionation in Ghana. Trop. Sci. 27, 77-84.

Habib W.; Basit Ali Shah S.; Wahidullah W. and Ghuftranullah (1991) The importance of ureamolasses blocks and by-pass protein in animal production. The situation in Pakistan. 133-145. In Isotope and Related Techniques in Animal Production and Health by International Atomic Energy. Vienna.

Hassoun $P$ and Ba A.A (1991) Mise all point d'nue technique de blocs multinutrionnels sams me lasse.Livestock Res. Rural Dev.2(2):72-82.

Ikhimoya I and Imasuen J.A (2007) Blood profile of West African Dwarf goats fed Panicum maximum supplemented with Afzelia Africana and New bouldia leaves. Pakistan Journal of Nutrition 6(1):79-84.

Jain N. C. (1993) Essentials of Veterinary Haematology. Lea and Febiger $\mathrm{Pu}$ blishers Malvern, Pennsylvania.

Karesh W. B and Cook R. A (1985) Application of veterinary medicine to in-situ conservation. Oryx 29: 244-252.

Lamb G. N. (1981) Manual of veterinary laboratory technique. CIBA-GEIGY, Kenya pp 96-107.

Mancini V. P.; Lebzein P.; Reinhardt R. and Flachowsky W. (1997) Studies on the influence of differently treated Molasses/Urea mixts. Vs Soyabean meal on parameters of rumen fermentation, duodenal nutrient flow and in sacco degradation of maize silage and wheat straw in non-lactating dairy cows. Anim. Res. and Dev. 46:75-86. 
Meyer D. J. and Harvey J. W. (1998) Veterinary laboratory medicine: Interpretation and Diagnosis 2nd edition. E. B. Saunders Company. An Imprint of Elsevier Science. Philadelphia Pannsylvaria. Pp. 346.

NAPRI (1984) Highlights of Research Achievements on Animal Production. Science and Technology Briefing Lagos December 1984 pp. 3-17.

Ogunsola T.A (2005) Influence of Roxazyme-G or Ronozyme-P on performance indices and meat quality of broiler- chickens fed diets containing Panicum maximum in place of maize. M.Tech Thesis. Federal University of Technology Akure pp 122.

Onwuka C. F. I. (1999) Molasses blocks as supplementary feed resources for ruminants. Arch. Zootech 48:89-94.

Onwuka C. F. I., Adeluyi W. O. Biobaku and Adu I. F. (1992) Leucaena leucocephala leaves in rabbit diets. Leucaena Research Reports 13: 65-67.
Orheruata A.M and Aikhuomobhogbe P .U (2006) Haematological and blood biochemical indices of West African Dwarf (WAD) goats vaccinated against pestes de petite ruminant (PPR). African Journal of Biotechnology 5:743-748.

Pickstock M. (1985) Molasses as drought feed for livestock Agric. Sci. Ddigest (M. E), 8:3.

Preston T. R. and Leng R. A. (1990) Matching ruminant production systems with available resources in the tropics and sub-tropics, CTA, Netherlands.

Steel R. G. B. and Torrie J. H. (1980) Principle and procedures of statistics. McGraw Hill book Co. N.Y.

Tambuwal F.M ; Agala B.M and Bangana A (2002) Haematological and biochemical values of apparently healthy red sokoto goats. In Proceedings of the $27^{\text {th }}$ Annual Conference of the Nigerian Society for Animal Production. 17-21 March 2002. Federal University Technology Akure, Nigeria.Pp50-53. 